\title{
Utilization of Black Soldier Fly (Hermetia illucens Linnaeus) Larvae as a Protein Source for Fish Feed: A Review
}

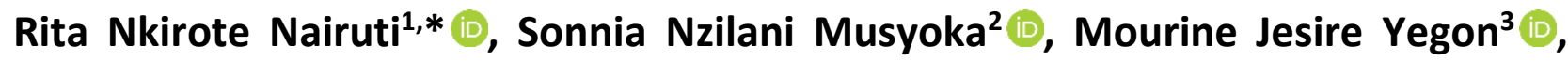 \\ Mary Adhiambo Opiyo ${ }^{1}$
}

\author{
${ }^{1}$ Kenya Marine and Fisheries Research Institute (KMFRI), National Aquaculture Research Development and Training \\ Center (NARDTC), P.O. Box 451-10230, Sagana, Kenya. \\ ${ }^{2}$ South Eastern Kenya University, Department of Hydrology and Aquatic Sciences, P.O. Box 170-90200, Kitui, Kenya. \\ ${ }^{3}$ University of Eldoret, School of Natural Resource Management, Department of Fisheries and Aquatic Sciences, P.O. \\ Box 1125-30100, Eldoret, Kenya.
}

\section{How to cite}

Nairuti, R.N., Musyoka, S.N., Yegon, M.J., Opiyo, M.A. (2022). Utilization of Black Soldier Fly (Hermetia illucens Linnaeus) Larvae as a Protein Source for Fish Feed - a Review. Aquaculture Studies, 22(2), AQUAST697. http://doi.org/10.4194/AQUAST697

\section{Article History}

Received 25 June 2021

Accepted 25 August 2021

First Online 27 August 2021

\section{Corresponding Author}

Tel.: +254701602471

E-mail: rnairuti@gmail.com

\section{Keywords}

Black soldier fly

Fish meal

Feed formulation

Nutritional value

Organic waste

\begin{abstract}
Aquaculture plays a major role in curbing malnutrition and food insecurity. Nonetheless, aquaculture sustainability is threatened by expensive fish feeds due to the overreliance on fish meal (FM) as the main source of protein. Fish meal is not only expensive but also scarce due to declining capture fisheries and competition from other animal feed producers. This has prompted research on potential FM replacers, amongst them the black soldier fly (BSF) larvae (Hermetia illucens). The BSF larvae can effectively convert organic wastes into a potential valuable feed source, and its high nutritional content (crude protein of up to $64 \%$ dry matter) is vital for fish feed formulation. Nevertheless, there are no documented studies on the complete replacement of FM in the diets of fish using BSF larvae. Therefore, the current study reviewed 107 research publications related to BSF larvae vis- $a$-vis fish feeds production to build capacity for existing theories, identify gaps, and suggest new and further research directions, based on the previous studies available in the area of larvae production and utilization in aquaculture nutrition. The study results are expected to help farmers make an informed decision on how to reduce the cost of fish production, increase yields, thus promoting food security, livelihoods, and ecological balance.
\end{abstract}

\section{Introduction}

The growing global human population coupled with the rising living standards are factors attributed to the high demand for animal-derived protein sources (Béné et al., 2016). Fish is one of the main sources of quality protein for the human population (Little et al., 2016). However, the aquaculture industry is faced with the challenge of fish feeds, which represents up to 60$70 \%$ of operational costs in fish production (Holeh et al., 2020). Fish meal and fish oil have over the years been the main source of protein and essential fats in aquatic feed production (Betancor et al., 2016). This is due to the high nutritional value of fish meal, balanced essential amino acids profile, high essential fatty acids, and phospholipids near to requirement levels of most cultivated aquatic organisms (NRC, 2011; Tacon et al, 2011). However, climate change, high global demand, and competition for fish meal and fish oil by both humans and other animal feed manufacturers have increased the pressure on global supplies coupled with rising market prices of the products (Van Huis et al., 2013; Tschirner and Simon, 2015; FAO, 2020). The use of non-conventional ingredients from both plant and animal-based sources have shown limited success in replacing fish meal due to unbalanced nutrition, presence of anti-nutritional factors and processing challenges (Amza and Tamiru, 2017; Hua et al., 2019; Mertenat et al., 2019, Musyoka et al., 2020). 
Insects have been a subject of discussion as potential replacements of fish meal in aquaculture because they contain relatively high protein levels with high availabilities for animals (Veldkamp et al., 2012; Van Huis et al., 2013; Bosch et al., 2014). Various species of Coleoptera and Diptera, including BSF (H. illucens) (Newton et al., 2005a), common houseflies (Musca domestica) (Awomyi, 2007) and beetles (Tenebrio molitor) (Li et al., 2013) that have been reared on lowgrade bio-wastes have effectively converted organic wastes into high-quality proteins. The BSF larvae appear to be superior among other insects as a potential source of protein in the fish feed formulations (Muin et al., 2017). This is due to its polyphagous, voracious nature and effectiveness in converting organic waste into highquality nutrients (Kim et al., 2011; Veldkamp et al., 2012). Moreover, BSF, being neither a non-vector nor a pest, is easy to culture in simple structures. In addition, it is known to reduce the presence of harmful bacteria from the food substrates (Erickson et al., 2004; Liu et al., 2008) and has a prebiotic effect on the fish (Gariglio et al., 2019). Successful dietary inclusion of BSF larvae in fish diets has shown improved fish yields and reduced production cost, thus promoting profitability and resource utilization.

\section{Review Method and Scope}

The scoping review methodology (Arksey and O'Malley, 2005) and systematic reviews approach were adopted in the present study to generate a comprehensive literature review on the potential of the BSF larvae as an alternative protein source in fish feed production. The literature review is focused on the nutritional value of BSF larvae, biotic and abiotic conditions that affect its performance and suitability as fish feed. To meet the set objectives, a wide range of keywords were searched in online database tools and scientific domains of Science Direct, Research Gate, Google Scholar and Web of Science to establish the value of $H$. illucens in terms of the utilization of fish feeds. The collected literature database was organized in copies, excerpts and notes according to topics. The current paper is a result of 107 research publications that met the inclusion criteria for the review paper.

\section{Basic Culture Method of Hermetia illucens}

\section{Biology and reproduction}

Understanding the biology, growth, survival and reproduction is vital for the utilization of BSF larvae as an ingredient for fish feed formulation. The BSF $(H$. illucens) belongs to the order Diptera and in the Stratiomyidae family (Awasthi et al., 2020). The $H$. illucens occurs in the tropical and sub-tropical regions of the world, and possess holometabolous metamorphosis (Dortmans et al., 2017). Their life cycle starts from an egg, which also marks the end of the previous life stage i.e., the female dies after laying eggs (Dortmans et al., 2017). A female fly lays 400 to 800 eggs in tiny, dry and well-sheltered cavities and close to a food source, preferably decomposing organic matter. This is to protect the eggs from predators and prevent dehydration of the egg packages from direct sunlight alongside increasing the chances of the survival of the larvae upon hatching (Dortmans et al., 2017). After hatching, the cream-like larvae take up large amounts of decomposing organic matter and increase from few millimeters to approximately $2.5 \mathrm{~cm}$ in length and 0.5 $\mathrm{cm}$ in width (Dortmans et al., 2017). The voracious feeding allows for the storage of enough fats and proteins to aid in the process of pupation, fly emergence, mating and oviposition.

Larval development takes a period of 14 to 16 days under optimal conditions (Shumo et al., 2019) as shown in Table 1. The optimum temperature required by BSF ranges between $26^{\circ} \mathrm{C}$ and $27^{\circ} \mathrm{C}$ (Dortmans et al., 2017). Temperatures above $30^{\circ} \mathrm{C}$ trigger the larvae to move away from the substrate in search of cooler areas while temperatures below $24^{\circ} \mathrm{C}$ reduce the metabolic activity of the insect leading to reduced growth (Holmes et al., 2016; Dortmans et al., 2017). The optimum relative humidity for growth of the BSF larvae ranges between $60-70 \%$, while the recommended substrate moisture ranges between 52-70\% (Holmes et al., 2012). Nevertheless, the BSF larvae have the ability to prolong their life cycle during unfavorable conditions (Shumo et al., 2019).

The pupae stage is symbolized by the replacement of the larval mouth-parts with a hook-shaped structure and the change in colour from cream to dark browncharcoal grey. The pupa uses its hook-shaped structure to move out and away from the substrate into a shaded and protected environment safe from predators (Zurbrügg et al., 2018). The pupation stage takes between two to three weeks and is marked by the transformation of the pupa into a fly. The emergent fly does not feed and is only dependent on water for development along the life cycle (Zurbrügg et al., 2018). During this phase, the adult searches for a partner, copulates and the female lays eggs. The flies have been found to prefer copulating in shaded areas during the morning light and females lay their eggs in well-shaded

Table 1. Abiotic factors for rearing black soldier fly (BSF). Adapted from (Barragan et al., 2017).

\begin{tabular}{lcccc}
\hline & Minimum & Optimal & Maximum & References \\
\hline Temperature $\left({ }^{\circ} \mathrm{C}\right)$ & 12 & $26-27$ & 36 & Holmes et al., 2016 \\
Relative Humidity (\%) & 25 & $60-70$ & 99 & Gobbi et al., 2013 \\
Substrate Moisture (\%) & 40 & $52-70$ & 70 & Holmes, 2010 \\
Light Intensity $/ \mathrm{m}^{2} / \mathrm{s}$ & 60 & $135-200$ & - & Zhang et al., 2010 \\
\hline
\end{tabular}


dark crevices near substrates (Au, 2021). Light intensity affects both the mating and egg fertilization of BSF (Zurbrügg et al., 2018). However, it has been suggested that light spectral composition plays a more important role in fertilization than light intensity. Light-emitting diodes producing wavelengths in the UV, blue and green ranges have proved to increase the proportion of fertilized eggs (Oonincx et al., 2016).

\section{Culture substrates for BSF larvae}

Like most organisms, the growth, production and maturation of $H$. illucens is highly dependent on the quantity and nutritional quality of the culture substrates as well as the environmental conditions. Adult BSF does not take up any food (Tomberlin, et al. 2002) but instead survives on the food reserves built up during the larval stage and water (Diener et al., 2011; Nguyen et al., 2015). It is only the larvae stage in the life cycle of the BSF that feeds. Therefore, successful larval growth and performance are highly influenced by the dietary composition of the substrates. Substrates rich in protein and carbohydrates result in good larval growth and translate to larvae with high crude protein and fats (Dortmans et al., 2017). Whereas, culture substrates that have high oily amounts produce larvae with high lipid levels, which subsequently translates to lower protein contents, because of the inverse relation of proteins and lipids in animal tissues (Mohanta et al., 2016; Musyoka et al., 2019).

The BSF is naturally found in and around faecal waste piles of livestock, poultry, swine and humans (Dortmans et al., 2017). Further, they are found colonizing domestic and industrial residues such as vegetable and fruit wastes, decaying coffee pulp and municipal organic effluents (Barragan et al., 2017). The presence of bacterial and fungal communities in these wastes acts as decomposition aids to further breakdown organic matter making it easier for the larvae to access the nutrients (Dortmans et al., 2017). In BSF culture units, the larvae can be fed with a wide range of organic residues, which are rich in nitrogen and calcium (Dortmans et al., 2017). The larvae prefer food substrates with moisture content between $52-70 \%$ but it exhibits phenotypic plasticity allowing them to adapt to any environmental variability (Tomberlin et al., 2002; Wang and Shelomi, 2017; Shumo et al., 2019).

It is important to note that, the popularization in the use of insects as food sources in the modern-day culture are closely tied with the issues of food safety. For example, in Europe there are more stringent rules and policies that prioritize risk avoidance such as those regarding insects as food sources. The EU framework terms BSF larvae as at risk of carrying biological and/or chemical food safety hazard as a function of feeding substrate (Wang and Shelomi, 2017). Nonetheless, as of May 2017, this regulation had identified seven insect species, Hermetia illucens included, that fulfill the safety conditions for insect production for farmed and pet animal feed. The regulation has however placed restrictions on the substrates fed to BSF larvae not to contain products of animal origin and not to be obtained from flesh and manure (human food waste) - EU Commission Regulation of 2017 (Tan et al., 2018).

On the other hand, the Food and Drug Administration (FDA) of USA only approves the utilization of dried larvae of Hermetia illucens cultured exclusively in feed grade substrates containing not less than $34 \%$ crude protein and $32 \%$ fat. Consequently, this regulation equally limits the rearing of BSF larvae destined for fish/chicken or human feed with kitchen wastes, animal manure or municipal wastes.

\section{Biochemical Composition of BSF Larvae in Relation to Fish Feed Production}

\section{Crude protein and fat content}

The BSF has a relatively higher crude protein (CP) and crude fat (CF) composition compared to other insects that have been utilized in the formulation of animal feeds among them: mealworm beetle (Tenebrio molitor) (Barroso et al., 2014), cricket (Gryllus campestris) (Rothman et al., 2014), drone fly (Eristalis tenax) (Kuntadi et al., 2018) and beetles; (Huang et al., 2019) (Table 2). Previous studies have reported BSF larvae to have relatively high protein and fat contents of up to $64 \%$ and $30 \%$, respectively. (St-Hilaire et al., 2007a; Zheng et al., 2012). The quality and quantity of substrate plays a big role in determining the body composition of the larvae (Gobbi et al., 2013; Nguyen et al., 2015). Newton et al. (2005b) and St-Hilaire et al. (2007b), reported higher protein contents in larvae fed on swine manure (43.6\%) than those fed cattle manure (42.1\%). Also, a study by Nguyen et al. (2015) found that larvae fed fish and liver contained more proteins and fats than those fed chicken feed. Similarly, several studies have reported higher fat content in larvae reared on cattle manure (34.8\%) in comparison to chicken (27.9\%) and swine manure (26.4\%) as shown in Table 3.

Further, the crude protein content of BSF larvae is influenced by the processing method. Higher CP

Table 2. Crude protein and crude fat contents in raw BSF (H. illucens) compared to mealworm beetle (Tenebrio molitor), cricket (Gryllus campestris) and Drone fly (Eristalis tenax), (g/100 g dry matter)

\begin{tabular}{lccc}
\hline Insect & Crude protein & Crude fat & References \\
\hline Mealworm beetle (Tenebrio molitor) & 38.3 & 26.7 & Kuntadi et al., 2018 \\
Cricket (Gryllus campestris) & 32.6 & 29.2 & Kuntadi et al., 2018 \\
Drone fly (Eristalis tenax) & 40.9 & 5.8 & Barroso et al., 2014 \\
BSF (H. illucens) & 42.0 & 36.2 & Huang et al., 2019 \\
\hline
\end{tabular}


contents have been recorded in highly defatted larvae as compared to partially defatted and full-fat larvae (Schiavone et al., 2017; Cardinaletti et al., 2019) as shown in Table 4. Defatting is usually done by freezing and cutting the larvae into small pieces (to allow the intracellular fat to leach out), pressing the flesh using tincture pressure at $60^{\circ} \mathrm{C}$ for 60 minutes, then finally drying the material for 20 hours in an oven at low temperature of about $60^{\circ} \mathrm{C}$ before grinding to a meal (Kroeckel et al., 2012). Besides, defatting of the larvae leads to lower amounts of fat content in the larvae making it easier for the formulation, grinding and pelletization of fish feeds (Briggs et al., 1999).

\section{Amino acid content}

Essential amino acids (AA) are vital nutrients that are considered when selecting a fish feed ingredient. These AA promote growth and reproduction rates alongside improving the disease resistance to aquatic organisms (Andersen et al., 2016; Musyoka et al., 2019). The AA content in BSF larvae is mainly influenced by the processing of the larvae. Defatting, which involves the mechanical or chemical removal of fat from the larvae has been found to help increase the amino acid content of dried BSF larvae meal (Andersen et al., 2016; Renna et al., 2017). Most studies have shown that the amino acid contents of the BSF larvae do not differ much (Table 5). Several studies have reported a relatively low methionine content of the BSF larvae meal when compared to fish meal. However, the BSF larvae meal have a good overall protein quality superior to fish meal and have higher contents of alanine, methionine, histidine, and tryptophan, but a lower content of arginine than soybean meal (Barragan et al., 2017).

\section{Fatty acids in BSF larvae}

The BSF larvae meal is rich in monounsaturated fats and has lower polyunsaturated fatty acid percentages than most insects such as the housefly maggots, mealworms, and adult crickets (Ghosh et al., 2017). Several studies have shown BSF larvae to contain between $58-72 \%$ saturated fatty acids and $19-40 \%$ mono and polyunsaturated fatty acids (Makkar et al., 2014; Surendra et al., 2016). Equally, the BSF larvae have been shown to contain high levels of lauric, palmitic and oleic acids (Surendra et al., 2016). The quality and quantity of fatty acid content in the BSF larvae are highly influenced by the type of substrate used. If the larvae are fed on lipid-rich animal diet, they accumulate more lipids in their bodies (which are more palatable to the fish) when compared to vegetable oils (Wang and Shelomi, 2017). Additionally, BSF larvae fed on fish offal have been reported to have relatively lower values of monosaturated fatty acids as compared to those fed on swine manure (Wang and Shelomi, 2017) an indication that the type of substate has an influence on the fatty acid of the larvae. When BSF were fed with fish byproducts, an increased levels of $n-3$ polyunsaturated fatty acids in their tissues were noted (Renna et al., 2017). St-Hilaire et al (2007a) reported an increase in the desirable fatty acids such as a-linolenic acid (ALA), eicosapentaenoic acid (EPA) and docosahexaenoic acid (DHA) when the larvae is fed on waste materials from fish processing plants. In addition, BSF larvae oil has been found to possess a good balance of saturated and unsaturated fatty acid (Makkar et al., 2014) (Table 6). Black soldier fly larvae provide the necessary fatty acids to meet the different nutritional requirements of different fish species (Table 7).

Table 3. Content of crude protein (CP) and crude fat (CF) of BSF larvae reared on different substrates. Adapted from (Barragan et al., 2017).

\begin{tabular}{lccc}
\hline Substrate & $\%$ CP* & $\%$ CF & References \\
\hline Cattle manure & 42.1 & 34.8 & Li et al., 2011b \\
Chicken manure & 40.1 & 27.9 & Arango et al., 2005 \\
Swine manure & $43.6 ; 43.2$ & 26.4 & St-Hilaire et al., 2007b; Li et al., 2011a \\
Palm kernel meal & $42.1 ; 45.8$ & 27.5 & Rachmawati et al., 2010 \\
Restaurant waste & - & 39.2 & Zheng et al., 2012 \\
Chicken feed & 47.9 & 14.6 & Bosch et al., 2014; Oonincx et al., 2015b \\
By-products* & 41.7 & - & Oonincx et al., 2015a \\
Liver & 62.7 & 25.1 & Nguyen et al., 2015 \\
Fruits and vegetables & $38.5 ; 30.84$ & $26.63 ; 33.10$ & Nguyen et al., 2015, Cardinaletti et al., 2019 \\
Fish & 57.9 & 34.6 & Nguyen et al., 2015 \\
\hline
\end{tabular}

${ }^{*}$ All values are expressed on a dry matter basis. ${ }^{* *}$ Beet molasses, potato steam peelings, spent grains and beer yeast, bread remains.

Table 4. Nutritional value of a partially defatted and a highly defatted BSF (BSF) larvae (H. illucens L.) meal.

\begin{tabular}{lccc}
\hline Nutrition & BSF full fat* meal & BSF partially defatted** meal & BSF highly defatted** meal $^{*}$ \\
\hline Dry matter, g/kg diet & 791 & 942 & 985 \\
Organic matter, g/kg DM & - & 901 & 907 \\
Crude protein, g/kg DM & 308 & 553 & 655 \\
Ether extract, g/kg DM & 331 & 180 & 46 \\
Gross energy, MJ/kg DM & - & 24.4 & 21.2 \\
Chitin, g/kg DM & - & 50 & 69 \\
\hline
\end{tabular}


Table 5. Amino acid profile of the BSF larvae (g/kg dry matter). Adapted from Spranghers et al., (2017).

\begin{tabular}{|c|c|c|c|c|}
\hline & Chicken feed & Digestate & Vegetable waste & Restaurant waste \\
\hline \multicolumn{5}{|c|}{ Essential amino acids } \\
\hline Isoleucine & 17.2 & 18.4 & 17.3 & 19.1 \\
\hline Leucine & 28.6 & 29.5 & 28 & 30.6 \\
\hline Lysine & 23.4 & 25.7 & 22.6 & 23 \\
\hline Arginine & 20.3 & 20.3 & 20 & 19.9 \\
\hline Methionine & 7.6 & 8.7 & 7.6 & 7.1 \\
\hline Histidine & 13.6 & 13.5 & 12.4 & 3.8 \\
\hline Phenylalanine & 17 & 18.7 & 16.3 & 16.4 \\
\hline Threonine & 16.4 & 16.8 & 15.4 & 16.2 \\
\hline \multicolumn{5}{|c|}{ Non-essential amino acids } \\
\hline Alanine & 25.2 & 24.3 & 24.2 & 27.8 \\
\hline Cystine & 2.5 & 2.4 & 2.1 & 2.2 \\
\hline Glutamic acid & 41.9 & 39.8 & 41.3 & 45.8 \\
\hline Glycine & 22.6 & 22.6 & 22.2 & 25.2 \\
\hline Proline & 22.5 & 22.1 & 21.4 & 25.1 \\
\hline Serine & 16.6 & 15.5 & 15 & 15.9 \\
\hline Aspartate & 37.8 & 33.6 & 35.9 & 36.9 \\
\hline Tryptophan & 6.7 & 6.2 & 5.8 & 5.4 \\
\hline Valine & 24.1 & 24.9 & 24.8 & 28.2 \\
\hline
\end{tabular}

\section{Mineral content in BSF larvae}

BSF larvae have superior mineral content when compared to most insects that have been used in the formulation of fish feeds (Dierenfeld and King, 2009). Previous studies have reported higher values of various minerals in black soldier fly larvae as compared to other insects like crickets (Acheta domesticus) and mealworm (Tenebrio molitor) that are utilized in fish feed formulation (Finke, 2013) (Table 8). Similarly, the mineral content in the BSF larvae is mainly influenced by the type of substrates used as shown in Table 9 (Fasakin et al., 2003). For instance, a study by Newton et al. (1977) reported higher levels of phosphorus in BSF larvae reared on poultry manure than those reared on swine manure. The BSF accumulate high concentrations of manganese $(\mathrm{Mn})$, iron (Fe), zinc $(\mathrm{Zn})$, copper $(\mathrm{Cu})$, phosphorus $(\mathrm{P})$ and calcium (Ca) but sodium or sulfur concentrations have been found in small quantities compared to the larvae in other insects (Wang and Shelomi, 2017). The high Ca concentration and ash contents ( 9 and $28 \%$ dry matter, respectively) in the larvae are attributed to the secretion of calcium carbonate $\left(\mathrm{CaCO}_{3}\right)$ by the epidermis (Finke, 2013; Makkar et al., 2014). On the other hand, the low Ca content $(0.03 \%)$ in the newly emerged adults has been attributed to the fact that the pupal cuticle that is concentrated with $\mathrm{Ca}$ is shed off to give rise to the adult fly (Finke, 2013).

\section{Chitin in BSF}

Chitin is a naturally occurring biopolymer that is made up of a mixture of mainly unbranched polymer of $\mathrm{N}$-acetyl-D-glucosamine and a small amount of $\mathrm{D}$ glucosamine (Soetemans et al., 2020). Chitosan is a common derivative of chitin produced by deacetylation reaction (Khayrova et al., 2019). In association with different assortments of cuticle and peritrophic matrix proteins, the yielded complex bio-composites have a wide range of physicochemical and mechanical properties that are important in healthcare, (waste) water treatment, agrochemicals, food and beverages and cosmetic application (Zhu et al., 2016). However, the crystalline nature of chitin is a major limitation in its utilization (Soetemans et al., 2020). Wang et al. (2020) recorded a gradual increase of the chitin crystalline index with development from larvae to adults i.e. $33.09 \%$ and $87.92 \%$, respectively. The same authors found a significant difference in the chitin contents of larvae, prepupae, puparium and adults of 3.6\%, 3.1\%, $14.1 \%$ and $2.9 \%$, respectively. In another study done by Soetemans et al. (2020), the chitin content in (larvae, prepupae, pupae, flies, shedding and cocoons) ranged between $8 \%$ to $24 \%$ of the total biomass with the cocoons and shedding recording the highest values. Likewise, Wang et al. (2020) indicated that the physicochemical structure of chitin was not significantly different in all the developmental stages of BSF (larvae, prepupa, puparium and adult). Chitin has been reported to be a non-digestible fibre that reduces the efficiency of nutrient absorption from the intestinal tract consequentially reducing the absorption and digestibility of lipids and proteins in animals (Razdan and Pettersson, 1994; Han et al., 2009).

Several studies have reported reduced feed intake and growth in different fish species mainly attributed to the low chitinase activity of the fish species. Chitin is said to decrease the lipid digestibility and inhibit nutrient absorption from the intestinal tract (Kroeckel et al., 2012). For instance, Gopalakannan and Arul (2006) and Olsen et al. (2006) reported a decrease in feed intake and growth in common carp (Cyprinus carpio), tilapia (Oreochromis niloticus $\times 0$. aureus), and Atlantic salmon (Salmo salar) at a dietary inclusion level of $1 \%$. Further, a dietary inclusion level of $10 \%$ chitin led to reduced 
Table 6. Fatty acid profile of the black soldier fly larvae (Data adapted and modified from (Larouche, 2019).

\begin{tabular}{lc}
\hline Fatty acid (\% lipid) & Larvae (a,b) \\
\hline Lauric (C12:0) & $29-61$ \\
Myristic (C14:0) & $7-10$ \\
Palmitic (C16:0) & $8-17$ \\
Palmitoleic (C16: 1n-7) & $3-7$ \\
Stearic (C18:0) & $1-3$ \\
Oleic (C18:1n-9) & $8-18$ \\
Linoleic (C18 :2n-6) & $4-17$ \\
Alpha-Linolenic (C18 :3n-3) & $0-2$ \\
Unsaturated fatty acid & $18-37$ \\
Saturated fatty acid & $58-80$ \\
\hline
\end{tabular}

a - Oonincx et al., 2015, ${ }^{\text {b }}$ Liu et al., 2017

Table 7. Fatty acid requirements of some fish species (Taşbozan \& Gökçe., 2017)

\begin{tabular}{lc}
\hline Species & Requirements of fatty acids (in dry feeds \%) \\
\hline Carnivores & Linolenic $1 \%$ \\
Rainbow trout (Oncorhynchus mykiss) & Linolenic $0.8 \%$ \\
& EPA + DHA $0.4-0.5 \%$ \\
Sea bass (Dicentrarchus labrax) & EPA+DHA $1 \%$ \\
Sea Bream (Sparus aurata) & EPA+DHA 1\%, EPA: DAHA $=1$ \\
Omnivores & EPA+DHA 1.9\%, EPA: DAHA= 0.5 \\
Common carp (Cyprinus carpio) & \\
Japanese eel (Anguilla japonicus) & Linoleic $1 \%$; Linolenic $0.5-1 \%$ \\
& Linoleic $0.5 \% ;$ Linolenic $0.5 \%$ \\
Herbivores & \\
Grass carp (Ctenopharyngodon Idella) & \\
Tilapia (Tilapia Zilli) & \\
Tilapia (Oreochromis niloticus) & Linoleic $1 \% ;$ Linolenic $0.5 \%$ \\
\hline
\end{tabular}

Table 8. Mineral contents of some insects reported by different authors.

\begin{tabular}{lcccc}
\hline & & Mealworm & \multicolumn{2}{c}{$\begin{array}{c}\text { Silkworm pupae (non } \\
\text { deffated) }\end{array}$} \\
Nutrient & Crickets (Dierenfeld \& King, 2009) & $\begin{array}{c}\text { Meldier fly larvae } \\
\text { (Klasing et al., } \\
\text { (Dierenfeld and King, 2009) }\end{array}$ & $\begin{array}{c}\text { 2000) } \\
\text { (Jintasataporn, 2012) }\end{array}$ \\
\hline $\mathrm{Ca}, \mathrm{g} / \mathrm{kg}$ & 1.6 & 31.4 & 2.7 & 3.8 \\
$\mathrm{P}, \mathrm{g} / \mathrm{kg}$ & 9.1 & 12.8 & 7.8 & 6 \\
$\mathrm{~K}, \mathrm{~g} / \mathrm{kg}$ & 12.1 & 19.6 & 8.9 & - \\
$\mathrm{Mg}, \mathrm{g} / \mathrm{kg}$ & 1.1 & 7.9 & 2.3 & 3.7 \\
$\mathrm{Na}, \mathrm{g} / \mathrm{kg}$ & 4.6 & 2.7 & 0.9 & - \\
$\mathrm{Cu}, \mathrm{mg} / \mathrm{kg}$ & 18.9 & 17 & 16 & 15 \\
$\mathrm{Fe}, \mathrm{mg} / \mathrm{kg}$ & 77.7 & 368 & 57 & 326 \\
$\mathrm{Mn}, \mathrm{mg} / \mathrm{kg}$ & 32.7 & 364 & 9.0 & 28 \\
\hline
\end{tabular}

Table 9. Means of mineral composition of BSF larvae reared on three different rearing substrates. Data adapted and modified from (Shumo et al., 2019)

\begin{tabular}{lcccc}
\hline Mineral/Substrate used & Cattle manure & Kitchen waste & Spent grain & Requirements by fish* \\
\hline Phosphorus & 3.9 & 4.1 & 4.6 & $7 \mathrm{~g}$ \\
Potassium & 4.9 & 5.7 & 4.4 & $1-3 \mathrm{~g}$ \\
Calcium & 3.2 & 2.0 & 1.7 & $5 \mathrm{~g}$ \\
Magnesium & 4.0 & 3.3 & 3.5 & $500 \mathrm{mg}$ \\
Iron & 0.6 & 2.2 & 0.3 & $50-100 \mathrm{mg}$ \\
Copper & 0.4 & 0.2 & $0.5 \mathrm{~b}$ & $1-4 \mathrm{~g}$ \\
Manganese & 1.4 & 0.9 & 1.1 & $20-50 \mathrm{mg}$ \\
Zinc & 0.3 & 0.3 & 0.3 & $30-100 \mathrm{mg}$ \\
\hline
\end{tabular}

Note: * - NRC (2011) 
growth and feed intake in rainbow trout (Oncorhynchus mykiss) (Lindsay et al., 1984). This has prompted studies to look into possibilities of isolating chitin from other nutritional constituents especially protein to improve the growth performances of the animals fed on diets containing BSF larvae. Separation of lipids from chitin is relatively easy as opposed to the separation of protein from chitin since the lipid is easily recovered by organic solvents. Separation of protein from chitin was carried out through alkali extraction whereby $96 \%$ of the protein was recovered (Caligiani et al., 2018). The extraction and production of chitosan involve the procedures: defatting, demineralization, dedeproteinization and deacetylation. The yielded chitosan is undertaken through an additional purification step by a reprecipitation from a solution in acetic acid (deacetylation reaction) that involves the removal of the acetyl groups from the chitin molecule (Khayrova et al., 2019).

\section{Utilization of BSF Larvae in Fish Feed Formulation}

Insect meals have been utilized in the formulation of fish feed diets for a very long time (Barragan et al., 2017). With BSF larvae having a higher reproductive capacity, short life cycle, ability to convert organic matter into high-quality protein and to thrive in a wide array of environments, the larvae have attracted enormous attention to be included in the formulation of fish diets (Barragan et al., 2017). Besides, the high protein content, digestibility and amino acid profiles of the BSF larvae have been the selling point for this meal in fish diets as shown in Table 10. The BSF meal has successfully replaced other conventional protein sources in the diets of Channel catfish (Ictalurus punctatus) (Bondari and Sheppard, 1981, 1987; Zhang et al., 2014a,b), blue tilapia (Oreochromis aureus) (Bondari and Sheppard, 1981, 1987), Nile tilapia (Oreochromis niloticus) (Muin et al., 2017), O. niloticus crossed with Sabaki tilapia (Oreochromis spilurus) (Furrer, 2011), rainbow trout (Oncorhynchus mykiss) (St-Hilaire et al., 2007b; Sealey et al., 2011), Atlantic salmon (Salmo salar) (Lock et al., 2015), turbot (Psetta maxima) (Kroeckel et al., 2012), yellow catfish (Tachysurus fulvidraco) (Zhang et al., 2014a) and African catfish (Clarius gariepinus) (Adewolu et al., 2010; Idowu and Afolayan, 2013).

The inclusion of BSF larvae meals in the diets of $O$. niloticus did not lead to any negative effects on the body weight gain (BWG) and specific growth rates (SGR) of the fish (Devic et al., 2018; Toriz- Roldan et al., 2019). Similarly, a partial or total dietary replacement of FM with BSF larvae meal did not lead to differences in the BWG and SGR of juvenile Japanese bass (Lateolabrax japonicus) and rainbow trout (Oncorhynchus mykiss),

Table 10. Summary of growth performance of different species of fish fed on BSF larvae meal diets. Bolded values represent the recommended replacement levels.

\begin{tabular}{|c|c|c|c|}
\hline Fish species tested & Attribute/element tested & $\begin{array}{l}\text { Replacement } \\
\text { levels (\%) }\end{array}$ & Author (s) \\
\hline $\begin{array}{l}\text { Jian carp (Cyprinus } \\
\text { carpio) }\end{array}$ & $\begin{array}{c}\text { A study by Li et al. } 2017 \text { suggested that it is possible to substitute up to } 100 \% \mathrm{FM} \\
\text { by BSF larvae meal in diets for Jian carp without negative effect on growth } \\
\text { performance and feed utilization efficiencies }\end{array}$ & $\begin{array}{c}0,25,50 \\
75,100\end{array}$ & $\begin{array}{l}\text { Li et al. } \\
\text { (2017) }\end{array}$ \\
\hline $\begin{array}{l}\text { Mearger } \\
\text { (Argyrosomus regius) } \\
\text { juvinilles }\end{array}$ & $\begin{array}{l}10 \% \text { of Hermetia illucens, can be included in Meagre diets without major adverse } \\
\text { effects on growth, feed utilization, whole-body composition and fatty acid profile, } \\
\text { further increase in the substitution rates lead to a negative effect on the growth } \\
\text { performance parameters }\end{array}$ & $10,20,30$ & $\begin{array}{l}\text { Guerreiro et } \\
\text { al. 2020) }\end{array}$ \\
\hline $\begin{array}{l}\text { Nile tilapia } \\
\text { (Oreochromis } \\
\text { niloticus) }\end{array}$ & $\begin{array}{l}\text { Replacement of soya protein concentrate by partly defatted BSF larvae meal up } \\
\text { to a level of } 50 \% \text { had no negative effect on growth performance and improved } \\
\text { the dietary protein quality of tilapia feeds under study }\end{array}$ & $25,50,100$ & $\begin{array}{c}\text { Dietz and } \\
\text { Liebert (2018) }\end{array}$ \\
\hline $\begin{array}{l}\text { Siberian sturgeon } \\
\text { (Acipenser baerii) }\end{array}$ & $\begin{array}{l}\text { Overall, this study showed that it is possible to replace up to } 25 \% \text { of FM with BSF } \\
\text { larvae meal in the diet of Siberian sturgeons (equal to } 18.5 \% \text { HIM inclusion level) } \\
\text { without affecting the growth performance }\end{array}$ & $25,50,100$ & $\begin{array}{l}\text { Caimi et al. } \\
\quad(2020)\end{array}$ \\
\hline $\begin{array}{l}\text { Rainbow trout } \\
\text { (Oncorhynchus } \\
\text { mykiss) }\end{array}$ & $\begin{array}{l}\text { The maximum inclusion of BSF larvae meal recommended in rainbow trout diets } \\
\text { is } 13 \% \text { further increase in the substitution lead to a decrease in the growth } \\
\text { parameters }\end{array}$ & $\begin{array}{c}0,6.6,13.2 \\
26.4\end{array}$ & $\begin{array}{c}\text { Dumas et al. } \\
\qquad(2018)\end{array}$ \\
\hline $\begin{array}{l}\text { Nile tilapia } \\
\text { (Oreochromis } \\
\text { niloticus) }\end{array}$ & $\begin{array}{l}\text { The study suggests that substitution of FM with BSF larvae upto } 100 \% \text { is possible } \\
\text { without any negative effects on the growth performance, feed utilization } \\
\text { efficiency, body composition }\end{array}$ & $\begin{array}{c}0,25,50,75 \\
100\end{array}$ & $\begin{array}{l}\text { Muin et al. } \\
\qquad(2017)\end{array}$ \\
\hline $\begin{array}{l}\text { European sea bass } \\
\text { (Dicentrarchus } \\
\text { labrax) }\end{array}$ & $\begin{array}{l}\text { With the } 3 \text { substitution levels of FM with BSF larvae meal at ( } 25,35,50 \%) \text {, BSF } \\
\text { larvae meal can effectively replace FM upto } 50 \% \text { without any negative effects on } \\
\text { the growth performance }\end{array}$ & $25,35,50$ & $\begin{array}{l}\text { Abdel- } \\
\text { Tawwab et al. } \\
\text { (2020) }\end{array}$ \\
\hline $\begin{array}{l}\text { Rice field eel } \\
\text { (Monopterus albus) }\end{array}$ & $\begin{array}{l}\text { Lower substitution rates }(5.26,10.52 \%) \text { of FM by BSF larvae meal in the diets of } \\
\text { Rice field eel, exhibited low values of the growth performance parameters as } \\
\text { compared to a higher substitution rates of FM by BSF larvae meal made at } \\
15.78 \%\end{array}$ & $\begin{array}{l}5.26,10.52 \\
\quad 15.78\end{array}$ & $\begin{array}{l}\text { Hu et al. } \\
\text { (2020) }\end{array}$ \\
\hline $\begin{array}{l}\text { African catfish } \\
\text { (Clarius gariepinus) }\end{array}$ & $\begin{array}{l}\text { Substitution of FM by BSF larvae up to } 75 \% \text { lead to no negative effects on the } \\
\text { growth performance and nutrient utilization }\end{array}$ & $0,25,50,75$ & $\begin{array}{l}\text { Fawole et al. } \\
\qquad(2020)\end{array}$ \\
\hline $\begin{array}{l}\text { Juvenille turbot } \\
\text { (Psetta maxima) }\end{array}$ & $\begin{array}{l}\text { The maximum inclusion of BSF larvae meal } \\
\text { recommended in Juvenile turbot diets is } 33 \% \text { further increase in the substitution } \\
\text { lead to a decrease in the growth performance parameters and nutrient utilization }\end{array}$ & $\begin{array}{l}0,17,33,49 \\
64,76\end{array}$ & $\begin{array}{l}\text { Kroeckel et al. } \\
\quad \text { (2012) }\end{array}$ \\
\hline
\end{tabular}


respectively (Wang and Shelomi, 2017; Belghit et al., 2019). A study by Fawole et al. (2020) on C. gariepinus found out that $50 \%$ replacement of FM with BSF larvae produced significantly higher values of final weight $(19.84 \mathrm{~g}, 14.79 \mathrm{~g})$, BWG $(15.83 \mathrm{~g}, 10.82 \mathrm{~g})$, protein efficiency ratio $(1.62,1.29)$, SGR $(2.66 \%, 2.19 \%)$ and feed intake $(23.26,20.09)$ as compared to control diet that contained $0 \%$ BSF larvae meal. Similarly, Muin et al. (2017) reported highest weight gain and SGR values of 8.74 and $2.43 \%$, respectively when BSF larvae meal was used to replace $\mathrm{FM}$ in the diets of $O$. niloticus with substitution at 0, 25, 50, 75 and $100 \%$. Additionally, BSF meal has shown to be a promising fish meal replacement in the diets of the pacific white shrimp (Litopenaeus vannamei) at a $25 \%$ inclusions level (Cummins et al., 2017). Importantly, the utilization of BSF larvae in fish feeds have shown the potential of lowering the production costs when compared to conventional feed sources such as FM and soyabean meal (Diener and Trockner, 2009). In Kenya the cost of BSF larvae ranges from 0.8 to $1.2 \mathrm{U} \$ \mathrm{D} / \mathrm{kg}$ while fish meal is from 1.2 to 1.5 $\mathrm{U} \$ \mathrm{D} / \mathrm{kg}$ and soybean meal is from 0.9 to $1.6 \mathrm{U} \$ \mathrm{D} / \mathrm{kg}$. These low costs of BSF larvae are associated with the low cost of feeding them (they feed on low value organic wastes) and the simplicity of the culture systems used (Diener and Trockner, 2009; van Huis, 2013).

\section{Conclusion}

The BSF larvae have a high potential of providing quality protein in fish diets thanks to their superior nutritional values, fostering good growth and reproduction rates. With proper culture systems and processing methods (principally to defatting and removing the chitin contents) the BSF is sustainable and can be better utilized to improve fish growth performance, reduced aquaculture production costs and improve resource utilization, thus promoting food security, livelihoods and ecological balance.

\section{Ethical Statement}

This is a review and all data used were not from lab experiments but rather from reviewing articles.

\section{Funding Information}

This study was conducted as part of baseline information for the Bioinnovate Africa Phase II project "Using Black Soldier Fly Larvae as an environmentally sustainable source of affordable protein for Chicken and Fish Feed, Project Ref: $\mathrm{BACl} 201812$. The project is being implemented with funding from the Swedish International Development Cooperation Agency (SIDA).

\section{Author Contribution}

RNN: Conceived the study, designed the methods, performed data curation, drafted and edited the original manuscript. SNM: Conceived the study, designed the methods, commented and edited the manuscript. MJY: Performed data curation, commented and edited the manuscript. MAO: Conceived the study, designed the methods, supervised the work, commented and edited the manuscript.

\section{Conflict of Interest}

The author(s) declare that they have no known competing financial or non-financial, professional, or personal conflicts that could have appeared to influence the work reported in this paper.

\section{References}

Abdel-Tawwab, M., Khalil, R.H., Metwally, A.A., Shakweer, M.S., Khallaf, M.A., and Abdel-Latif, H.M. (2020). Effects of black soldier fly (Hermetia illucens L.) larvae meal on growth performance, organs-somatic indices, body composition and hemato-biochemical variables of European sea bass, Dicentrarchus labrax. Aquaculture. 522: 735136.

https://doi.org/10.1016/j.aquaculture.2020.735136

Adewolu, M.A., Ikenweiwe, N.B., and Mulero, S.M. (2010). Evaluation of an animal protein mixture as a replacement for fish meal in practical diets for fingerlings of Clarias gariepinus (Burchell, 1822). Israel Journal of Aquaculture-Bamidgeh. 62(4): 237-244.

Amza, N., and Tamiru, M. (2017). Insects as an option to conventional protein sources in animal feed: A review paper. Global Journal of Science Frontier Research: D Agriculture and Veterinary. 17: 12.

Andersen, S.M., Waagbo, R., and Espe, M. (2016). Functional amino acids in fish nutrition, health and welfare. National Institute of Nutrition and Seafood Research (NIFES). Frontiers in Bioscience. 8: 143-169. https://doi.org/10.2741/757

Arango Gutiérrez, G.P., Vergara Ruiz, R.A., and Mejía Vélez, H. (2005). Compositional, microbiological and protein digestibility analysis of the larva meal of Hermetia illucens L. (Diptera: Stratiomyidae) at AngelópolisAntioquia, Colombia. Revista Facultad Nacional de Agronomía Medellín. 57: 2491-2500.

Arksey, H., and O'Malley, L. (2005). Scoping studies: Towards a methodological framework. International Journal of Social Research Methodology. 8: 19-32. https://doi.org/10.1080/1364557032000119616

$\mathrm{Au}$, Julius. (2021). Black soldier fly cultivation: conditions and a proposed method. Creative Components. https://lib.dr.iastate.edu/creativecomponents/707

Awasthi, M.K., Liu, T., Awasthi, S.K., Duan, Y., Pandey, A., and Zhang, Z. (2020). Manure pretreatments with black soldier fly Hermetia illucens L. (Diptera: Stratiomyidae): A study to reduce pathogen content. Science of The Total Environment. 737: 139842. https://doi.org/10.1016/j.scitotenv.2020.139842

Awomyi, T. (2007). Health, nutritional and consumers' acceptability assurance of maggot meal inclusion in livestock diet: a review. International Journal of Tropical Medicine. 2: 52-56.

Barragan-Fonseca, K.B., Dicke, M., and van Loon, J.J. (2017). Nutritional value of the black soldier fly (Hermetia illucens L.) and its suitability as animal feed-a review. 
Journal of Insects as Food and Feed. 3(2): 105 - 120. https://doi.org/10.3920/JIFF2016.0055

Barroso FG, de Haro C, Sánchez-Muros M-J, Venegas E, Martínez-Sánchez A., and Pérez-Bañón C. (2014). The potential of various insect species for use as food for fish. Aquaculture. 422-423, 193-201. https://doi.org/10.1016/j.aquaculture.2013.12.024

Belghit, I., Liland, N.S., Gjesdal, P., Biancarosa, I., Menchetti, E., Li, Y., and Lock, E.J. (2019). Black soldier fly larvae meal can replace fish meal in diets of sea-water phase Atlantic salmon (Salmo salar). Aquaculture. 503: 609 - 619. https://doi.org/10.1016/j.aquaculture.2018.12.032

Béné, C., Arthur, R., Norbury, H., Allison, E.H., Beveridge, M., Bush, S., Campling, L., Leschen, W., Little, D., Squires, D., Thilsted, S.H., Troell, M., and Williams, M. (2016). Contribution of fisheries and aquaculture to food security and poverty reduction: Assessing the current evidence. World Development. 79: 177-196. https://doi.org/10.1016/j.worlddev.2015.11.007

Betancor, M.B., Sprague, M., Montero, D., Usher, S., Sayanova, O., Campbell, P.J., Napier, J.A., Caballero, M.J., Izquierdo, M., and Tocher, D.R. (2016). Replacement of Marine Fish Oil with de novo Omega-3 Oils from Transgenic Camelina sativa in Feeds for Gilthead Sea Bream (Sparus aurata L.). Lipids. 51(10): 1171-1191. https://doi.org/10.1007/s11745-016-4191-4

Bondari, K., and Sheppard, D.C. (1981). Soldier fly larvae as feed in commercial fish production. Aquaculture. 24: 103109. https://doi.org/10.1016/0044-8486(81)90047-8

Bondari, K., and Sheppard, D.C. (1987). Soldier fly, Hermetia illucens L., larvae as feed for channel catfish, Ictalurus punctatus (Rafinesque), and blue tilapia, Oreochromis aureus (Steindachner). Aquaculture and Fisheries Management. 18: 209-220. https://doi.org/10.1111/j.1365-2109.1987.tb00141.x

Bosch, G., Zhang, S., Oonincx, D.G.A.B. and Hendriks, W.H. (2014). Protein quality of insects as potential ingredients for dog and cat foods. Journal of Nutritional Science. 3(e29): 1-4. https://doi.org/10.1017/jns.2014.23

Briggs, J.L., Maier, D.E., Watkins, B.A. and Behnke, K.C. (1999). Effect of ingredients and processing parameters on pellet quality. Poultry Science. 78: 1464-1471. https://doi.org/10.1093/ps/78.10.1464

Caimi, C., Renna, M., Lussiana, C., Bonaldo, A., Gariglio, M., Meneguz, M., and Gasco, L. (2020). First insights on Black Soldier Fly (Hermetia illucens L.) larvae meal dietary administration in Siberian sturgeon (Acipenser baerii Brandt) juveniles. Aquaculture. 515: 734539. https://doi.org/10.1016/j.aquaculture.2019.734539

Caligiani, A., Marseglia, A., Leni, G., Baldassarre, S., Maistrello, L., Dossena, A., and Sforza, S. (2018). Composition of black soldier fly prepupae and systematic approaches for extraction and fractionation of proteins, lipids and chitin. Food Research International. 105: 812-820. https://doi.org/10.1016/j.foodres.2017.12.012

Cardinaletti, Gloriana., Randazzo, Basilio., Messina, Maria., Zarantoniello, Matteo., Giorgini, Elisabetta., Zimbelli, Andrea., Bruni, Leonardo., Parisi, Giuliana., Olivotto, Ike., and Tulli, Francesca. (2019). Effects of Graded Dietary Inclusion Level of Full-Fat Hermetia illucens Prepupae Meal in Practical Diets for Rainbow Trout (Oncorhynchus mykiss). Animals. 9(5): 251.

https://doi.org/10.3390/ani9050251

Cummins, V.C., Rawles, S.D., Thompson, K.R., Velasquez, A., Kobayashi, Y., Hager, J., and Webster, C.D. (2017).
Evaluation of black soldier fly (Hermetia illucens) larvae meal as partial or total replacement of marine fish meal in practical diets for Pacific white shrimp (Litopenaeus vannamei). Aquaculture. 473: 337 - 344.

https://doi.org/10.1016/j.aquaculture.2017.02.022

Devic, E., Leschen, W., Murray, F., and Little, D.C. (2018). Growth performance, feed utilization and body composition of advanced nursing Nile tilapia (Oreochromis niloticus) fed diets containing black soldier fly (Hermetia illucens) larvae meal. Aquaculture nutrition. 24(1): 416 - 423.

https://doi.org/10.1111/anu.12573

Diener, S., Zurbrügg, C., Gutiérrez, F.R., Nguyen, D.H., Morel, A., Koottatep, T., and Tockner, K. (2011). Black soldier fly larvae for organic waste treatment-prospects and constraints. Proceedings of the WasteSafe. 2: 13-15. https://doi.org/10.1007/s12649-011-9079-1

Dierenfeld, E.S. and King, J. (2009). Digestibility and mineral availability of phoenix worms (Hermetia illucens) ingested by mountain chicken frogs (Leptodactylus fallax). Journal of Herpetological Medicine and Surgery. 18: 100-105. https://doi.org/10.5818/1529-9651.18.34.100

Dietz, C., and Liebert, F. (2018). Does graded substitution of soy protein concentrate by an insect meal respond on growth and $\mathrm{N}$-utilization in Nile tilapia (Oreochromis niloticus)? Aquaculture Reports. 12: 43-48. https://doi.org/10.1016/j.aqrep.2018.09.001

Dortmans, B., Diener, S., Bart, V., and Zurbrügg, C. (2017). Black soldier fly biowaste processing: A Step-by-Step Guide. eawag.

Dumas, A., Raggi, T., Barkhouse, J., Lewis, E., and Weltzien, E. (2018). The oil fraction and partially defatted meal of black soldier fly larvae (Hermetia illucens) affect differently growth performance, feed efficiency, nutrient deposition, blood glucose and lipid digestibility of rainbow trout (Oncorhynchus mykiss). Aquaculture. 492: 24-34. https://doi.org/10.1016/j.aquaculture.2018.03.038

Erickson, M.C., Islam, M., Sheppard, C., Liao, J., and Doyle, M.P. (2004). Reduction of Escherichia coli 0157:H7 and Salmonella enterica serovar enteritidis in chicken manure by larvae of the black soldier fly. Journal of Food Protection. 67: 685-690. https://doi.org/10.4315/0362028X-67.4.685

FAO. (2020). The State of World Fisheries and Aquaculture 2020. Sustainability in action. Rome.

Fasakin, E.A., Balogun, A.M., and Ajayi, O.O. (2003). Evaluation of full-fat and defatted maggot meals in the feeding of clariid catfish Clarias gariepinus fingerlings. Aquaculture Resource. 34: 733 - 738. https://doi.org/10.1046/j.1365-2109.2003.00876.x

Fawole, F.J., Adeoye, A.A., Tiamiyu, L.O., Ajala, K.I., Obadara, S.O., and Ganiyu, I.O. (2020). Substituting fishmeal with Hermetia illucens in the diets of African catfish (Clarias gariepinus): Effects on growth, nutrient utilization, haemato-physiological response, and oxidative stress biomarker. Aquaculture. 518, 734849.

https://doi.org/10.1016/j.aquaculture.2019.734849

Finke, M.D. (2013). Complete nutrient content of four species of feeder insects. Zoo Biology. 32: 27-36. https://doi.org/10.1002/zoo.21012

Furrer, T. (2011). Finding an adequate tilapia feed for rural fish farmers in Mombasa. BSc thesis, Zurich University of Applied Sciences, Winterthur, Switzerland. 
http://tinyurl.com/mblptmd

Gariglio, M., Dabbou, S., Biasato, I., Capucchio, M.T., Colombino, E., Hernández, F., and Schiavone, A. (2019). Nutritional effects of the dietary inclusion of partially defatted Hermetia illucens larva meal in Muscovy duck. Journal of animal science and biotechnology. 10(1): 37. https://doi.org/10.1186/s40104-019-0344-7

Ghosh, S., Lee, S. M., Jung, C., and Meyer-Rochow, V.B. (2017). Nutritional composition of five commercial edible insects in South Korea. Journal of Asia-Pacific Entomology. 20: 686-694. https://doi.org/10.1016/j.aspen.2017.04.003

Gobbi, P., Martínez-Sánchez, A., and Rojo, S. (2013). The effects of larval diet on adult life-history traits of the black soldier fly, Hermetia illucens (Diptera: Stratiomyidae). European Journal of Entomology. 110, 461. https://doi.org/10.14411/eje.2013.061

Gopalakannan, A., and Arul, V. (2006). Immunomodulatory effects of dietary intake of chitin, chitosan and levamisole on the immune system of Cyprinus carpio and control of Aeromonas hydrophila infection in ponds. Aquaculture. 255(1-4): 179-187. https://doi.org/10.1016/j.aquaculture.2006.01.012

Guerreiro, I., Castro, C., Antunes, B., Coutinho, F., Rangel, F., Couto, A., and Enes, P. (2020). Catching black soldier fly for meagre: Growth, whole-body fatty acid profile and metabolic responses. Aquaculture. 516: 734613. https://doi.org/10.1016/j.aquaculture.2019.734613

Han, Y., Yang, B., Zhang, F., Miao, X., and Li, Z. (2009). Characterization of antifungal chitinase from marine Streptomyces sp. DA11 associated with South China Sea sponge Craniella australiensis. Marine Biotechnology. 11(1): 132. https://doi.org/10.1007/s10126-008-9126-5

Holeh, G.M., Appanteng, P., Opiyo, M.A., Park, J., and Brown, C.L. (2020). Effects of intermittent feeding regimes on growth performance and economic benefits of Amur catfish (Silurus asotus). Aquatic Research. 3(3): 167-176. https://doi.org/10.3153/AR20015

Holmes, L., Van Laerhoven, S., and Tomberlin, J. (2016). Lower temperature threshold of black soldier fly (Diptera: Stratiomyidae) development. Journal of Insects as Food and Feed. 2: 1-8. https://doi.org/10.3920/JIFF2016.0008

Holmes, L.A. (2010). Role of abiotic factors on the development and life history of the black soldier fly, Hermetia illucens (L.) (Diptera: Stratiomyidae). PhD thesis, University of Windsor, Windsor, ON, Canada. http://tinyurl.com/n6cc2cc

Holmes, L.A., Van laerhoven, S.L., and Tomberlin, J.K. (2012). Relative humidity effects on the life history of Hermetia illucens (Diptera: Stratiomyidae). Environmental Entomology. 41: 971-978.

https://doi.org/10.1603/EN12054

$\mathrm{Hu}$, Y., Huang, Y., Tang, T., Zhong, L., Chu, W., Dai, Z., and Hu, Y. (2020). Effect of partial black soldier fly (Hermetia illucens L.) larvae meal replacement of fish meal in practical diets on the growth, digestive enzyme and related gene expression for rice field eel (Monopterus albus). Aquaculture Reports. 17, 100345. https://doi.org/10.1016/j.aqrep.2020.100345

Hua, K., Cobcroft, J. M., Cole, A., Condon, K., Jerry, D. R., Mangott, A., and Strugnell, J. M. (2019). The future of aquatic protein: implications for protein sources in aquaculture diets. One Earth. 1(3): 316-329. https://doi.org/10.1016/j.oneear.2019.10.018
Huang, C., Feng, W., Xiong, J., Wang, T., Wang, W., Wang, C., and Yang, F. (2019). Impact of drying method on the nutritional value of the edible insect protein from black soldier fly (Hermetia illucens L.) larvae: Amino acid composition, nutritional value evaluation, in vitro digestibility, and thermal properties. European Food Research and Technology. 245(1): 11-21. https://doi.org/10.1007/s00217-018-3136-y

Idowu, E., and Afolayan, E. (2013). The effects of supplementing of fish meal with maggots at varying levels in the diet of Clarias gariepinus. International archive of applied sciences and technology. 4: 41 - 47.

Jintasataporn, O. (2012). Production performance of broiler chickens fed with silkworm pupa (Bombyx mori). J. Agric. Sci. Technol. ISSN 1939-1250.

Khayrova, A., Lopatin, S., and Varlamov, V. (2019). Black soldier fly Hermetia illucens as a novel source of chitin and chitosan. International Journal of Sciences. 8(4): 81-86. https://doi.org/10.18483/ijSci.2015

Kim, W., Bae, S., Kim, A., Park, K., Lee, S., Choi, Y., Han, S., Park, Y., and Koh, Y. (2011). Characterization of the molecular features and expression patterns of two serine proteases in Hermetia illucens (Diptera: Stratiomyidae) larvae. BMB Reports. 44: 387. https://doi.org/10.5483/BMBRep.2011.44.6.387

Klasing, K.C., Thacker, P., Lopez, M.A., Calvert, C.C. (2000). Increasing the calcium content of mealworms (Tenebrio molitor) to improve their nutritional value for bone mineralization of growing chicks. J. Zoo. Wildl. Med. 31, 512e517

Kroeckel, S., Harjes, A.G.E., Roth, I., Katz, H., Wuertz, S., Susenbeth, A., and Schulz, C. (2012). When a turbot catches a fly: evaluation of a pre-pupae meal of the black soldier fly (Hermetia illucens) as fish meal substitute Growth performance and chitin degradation in juvenile turbot (Psetta maxima). Aquaculture and Fisheries Management. 364-365, 345-352. https://doi.org/10.1016/j.aquaculture.2012.08.041

Kuntadi, K., Adalina, Y., and Maharani, K.E.F. (2018). Nutritional compositions of six edible insects in Java. Indonesian journal of forestry research. 5(1): 57-68. https://doi.org/10.20886/ijfr.2018.5.1.57-68

Larouche, J. (2019). Processing methods for the black soldier fly (Hermetia illucens) larvae: from feed withdrawal periods to killing methods.

Li, L., Zhao, Z., and Liu, H. (2013). Feasibility of feeding yellow mealworm (Tenebrio molitor L.) in bioregenerative life support systems as a source of animal protein for humans. Acta Astronautica. 92: 103-109. https://doi.org/10.1016/j.actaastro.2012.03.012

Li, Q., Zheng, L., Cai, H., Garza, E., Yu, Z., and Zhou, S. (2011a). From organic waste to biodiesel: black soldier fly, Hermetia illucens, makes it feasible. Fuel, 90: 1545-1548. https://doi.org/10.1016/j.fuel.2010.11.016

Li, Q., Zheng, L., Hou, Y., Yang, S., and Yu, Z. (2011b). Insect fat, a promising resource for biodiesel. Journal of Petroleum and Environmental Biotechnology S2: 001.

Li, S., Ji, H., Zhang, B., Zhou, J., and Yu, H. (2017). Defatted black soldier fly (Hermetia illucens) larvae meal in diets for juvenile Jian carp (Cyprinus carpio var. Jian): Growth performance, antioxidant enzyme activities, digestive enzyme activities, intestine and hepatopancreas histological structure. Aquaculture. 477: 62-70. https://doi.org/10.1016/j.aquaculture.2017.04.015 
Lindsay, G.J., Walton, M.J., Adron, J.W., Fletcher, T.C., Cho, C.Y., and Cowey, C.B. (1984). The growth of rainbow trout (Salmo gairdneri) given diets containing chitin and its relationship to chitinolytic enzymes and chitin digestibility. Aquaculture. 37(4): 315-334. https://doi.org/10.1016/0044-8486(84)90297-7

Little, D.C., Newton, R.W., and Beveridge, M.C.M. (2016). Aquaculture: a rapidly growing and significant source of sustainable food? Status, transitions and potential. Proceedings of the Nutrition Society. 75(3): 274-286. https://doi.org/10.1017/S0029665116000665

Liu, Q., Tomberlin, J.K., Brady, J.A., Sanford, M.R., and Yu, Z. (2008). Black soldier fly (Diptera: Stratiomyidae) larvae reduce Escherichia coli in dairy manure. Environmental Entomology. 37: 1525-1530.

https://doi.org/10.1603/0046-225X-37.6.1525

Liu, X.; Chen, X.; Wang, H.; Yang, Q.; Ur Rehman, K.; Li, W.; Cai, M.; Li, Q.; Mazza, L.; Zhang, J.; Yu, Z.; Zheng, L. (2017). Dynamic changes of nutrient composition throughout the entire life cycle of black soldier fly. PloS One 12 (8), e0182601

Lock, E., Arsiwalla, T., and Waagb $\varnothing$, R. (2015). Insect larvae meal as an alternative source of nutrients in the diet of Atlantic salmon (Salmo salar) postsmolt. Aquaculture Nutrition. 22: 1202-1213. https://doi.org/10.1111/anu.12343

Makkar, H.P.S., Tran, G., Heuzé, V., and Ankers, P. (2014). State of the art on use of insects as animal feed. Animal Feed science and Technology. 197: 1 - 33. https://doi.org/10.1016/j.anifeedsci.2014.07.008

Mertenat, A., Diener, S., and Zurbrügg, C. (2019). Black soldier fly biowaste treatment- Assessment of global warming potential. Waste management. 84: 173 - 181. https://doi.org/10.1016/j.wasman.2018.11.040

Mohanta, K.N., Subramanian, S., and Korikanthimath, V.S. (2016). Potential of earthworm (Eisenia fetida) as dietary protein source for rohu (Labeo rohita) advanced fry. Cogent Food \& Agriculture. 2(1): 1138594. https://doi.org/10.1080/23311932.2016.1138594

Muin, H., Taufek, N.M., Kamarudin, M.S., and Razak, S.A. (2017). Growth performance, feed utilization and body composition of Nile tilapia, Oreochromis niloticus (Linnaeus, 1758) fed with different levels of black soldier fly, Hermetia illucens (Linnaeus, 1758) maggot meal diet. Iranian Journal of Fisheries Sciences. 16(2): 567 - 577.

Musyoka, S.N., Liti, D.M., Ogello, E., and Waidbacher, H. (2019). Utilization of the earthworm, Eisenia fetida (Savigny, 1826) as an alternative protein source in fish feeds processing: A review. Aquaculture Research. 50(9): 2301 - 2315. https://doi.org/10.1111/are.14091

Musyoka, S.N., Liti, D.M., Ogello, E., Meulbroek P., and Waidbacher, H. (2020). Using Earthworm, Eisenia fetida, to Bio-convert Agro-industrial Wastes for Aquaculture Nutrition. BioResources. 15(1): 574-587.

https://doi.org/10.15376/biores.15.1.574-587

Newton, G.L., Booram, C.V., Barker, R.W. and Hale, O.M. (1977). Dried Hermetia illucens larvae meal as supplement for swine. Journal of Animal Science. 44: 395-400.

https://doi.org/10.2527/jas1977.443395x

Newton, G.L., Sheppard, D.C., Watson, D.W., Burtle, G.J., Dove, C.R., Tomberlin, J.K., and Thelen, E.E. (2005a). The black soldier fly, Hermetia illucens, as a manure management/resource recovery tool. In: Proceedings of the Symposium State of the Science, Animal Manure and
Waste Management, January 5-7 2005, San Antonio, TX, USA.

Newton, L., Sheppard, C., Watson, D.W., and Burtle, G. (2005b). Using the black soldier fly, Hermetia illucens, as a value-added tool for the management of swine manure. Report for Mike Williams, Director of the Animal and Poultry Waste Management Centre, North Carolina State University, Raleigh, NC, USA. http://tinyurl.com/mxam64v

Nguyen, T.T., Tomberlin, J.K., and Vanlaerhoven, S. (2015). Ability of black soldier fly (Diptera: Stratiomyidae) larvae to recycle food waste. Environmental Entomology. 44: 406-410. https://doi.org/10.1093/ee/nvv002

National Research Council (NRC). (2011). Nutrient requirements of fish and shrimp. National Academy Press, Washington, DC, USA. https://doi.org/10.17226/13039

Olsen, R.E., Suontama, J., Langmyhr, E., Mundheim, H., Ring $\varnothing$, E., Melle, W., and Hemre, G.I. (2006). The replacement of fish meal with Antarctic krill, Euphausia superba in diets for Atlantic salmon, Salmo salar. Aquaculture Nutrition. 12(4): 280-290. https://doi.org/10.1111/j.1365-2095.2006.00400.x

Oonincx, D.G.A.B., Van Huis, A., and Van Loon, J.J.A. (2015a). Nutrient utilization by black soldier flies fed with chicken, pig, or cow manure. Journal of Insects as Food and Feed. 1: 131-139. https://doi.org/10.3920/JIFF2014.0023

Oonincx, D.G.A.B., Van Broekhoven, S., Van Huis, A., and Van Loon, J.J.A. (2015b). Feed conversion, survival and development, and composition of four insect species on diets composed of food byproducts. PLoS ONE, 10, e0144601.

https://doi.org/10.1371/journal.pone.0144601

Oonincx, D.G.A.B., Volk, N., Diehl, J.J.E., Van Loon, J.J.A., and Belušič, G. (2016). Photoreceptor spectral sensitivity of the compound eyes of black soldier fly (Hermetia illucens) informing the design of LED-based illumination to enhance indoor reproduction. Journal of insect physiology. 95: 133-139. https://doi.org/10.1016/j.jinsphys.2016.10.006

Rachmawati, R., Buchori, D., Hidayat, P., Hem, S., and Fahmi, M.R. (2010). Perkembangan dan kandungan nutrisi larva Hermetia illucens (Linnaeus) (Diptera: Stratiomyidae) pada bungkil kelapa sawit. Journal Entomology Indonesia. 7: 28-41. https://doi.org/10.5994/jei.7.1.28

Razdan, A., and Pettersson, D. (1994). Effect of chitin and chitosan on nutrient digestibility and plasma lipid concentrations in broiler chickens. British Journal of Nutrition. 72(2): 277-288. https://doi.org/10.1079/BJN19940029

Renna, M., Schiavone, A., Gai, F., Dabbou, S., Lussiana, C., Malfatto, V., and Gasco, L. (2017). Evaluation of the suitability of a partially defatted black soldier fly (Hermetia illucens L.) larvae meal as ingredient for rainbow trout (Oncorhynchus mykiss Walbaum) diets. Journal of Animal Science and Biotechnology. 8(1):1-13. https://doi.org/10.1186/s40104-017-0191-3

Rothman, J.M., Raubenheimer, D., Bryer, M.A., Takahashi, M., and Gilbert, C.C. (2014). Nutritional contributions of insects to primate diets: implications for primate evolution. The Journal of Human Evolution. 71: 59-69. https://doi.org/10.1016/j.jhevol.2014.02.016

Schiavone, A., De Marco, M., Martínez, S., Dabbou, S., Renna, M., Madrid, J., and Gasco, L. (2017). Nutritional value of a partially defatted and a highly defatted black soldier fly 
larvae (Hermetia illucens L.) meal for broiler chickens: apparent nutrient digestibility, apparent metabolizable energy and apparent ileal amino acid digestibility. Journal of animal science and biotechnology. 8(1): 51. https://doi.org/10.1186/s40104-017-0181-5

Sealey, W.M., Gaylord, T.G., Barrows, F.T., Tomberlin, J.K., McGuire, M.A., Ross, C., and St-Hilaire, S. (2011). Sensory analysis of rainbow trout, Oncorhynchus mykiss, fed enriched black soldier fly prepupae, Hermetia illucens. Journal of the World Aquaculture Society. 42: 34-45. https://doi.org/10.1111/j.1749-7345.2010.00441.x

Shumo, M., Khamis, F.M., Tanga, C.M., Fiaboe, K.K., Subramanian, S., Ekesi, S., and Borgemeister, C. (2019). Influence of temperature on selected life-history traits of black soldier fly (Hermetia illucens) reared on two common urban organic waste streams in Kenya. Animals. 9(3): 79. https://doi.org/10.3390/ani9030079

Soetemans, L., Uyttebroek, M., and Bastiaens, L. (2020). Characteristics of chitin extracted from black soldier fly in different life stages. International Journal of Biological Macromolecules. 165: 3206-3214.

https://doi.org/10.1016/j.ijbiomac.2020.11.041

Spranghers, T., Ottoboni, M., Klootwijk, C., Ovyn, A., Deboosere, S., De Meulenaer, B., and De Smet, S. (2017). Nutritional composition of black soldier fly (Hermetia illucens) prepupae reared on different organic waste substrates. Journal of the Science of Food and Agriculture. 97(8): 2594-2600. https://doi.org/10.1002/jsfa.8081

St-Hilaire, S., Cranfill, K., Mcguire, M.A., Mosley, E.E., Tomberlin, J.K., Newton, L., Sealey, W., Sheppard, C., and Irving, S. (2007a). Fish offal recycling by the black soldier fly produces a food stuff high in omega-3 fatty acids. Journal of the World Aquaculture Society. 38: 309-313. https://doi.org/10.1111/j.1749-7345.2007.00101.x

St-Hilaire, S., Sheppard, C., Tomberlin, J.K., Irving, S., Newton, L., McGuire, M.A., Mosley, E.E., Hardy, R.W., and Sealey, W. (2007b). Fly prepupae as a feedstuff for rainbow trout, Oncorhynchus mykiss. Journal of the World Aquaculture Society. 38: 59-67. https://doi.org/10.1111/j.1749-7345.2006.00073.x

Surendra, K., Olivier, R., Tomberlin, J.K., Jha, R., and Khanal, S.K. (2016). Bioconversion of organic wastes into biodiesel and animal feed via insect farming. Renewable Energy. 98: 197-202.

https://doi.org/10.1016/j.renene.2016.03.022

Tacon, A.G.J., Hasan, M.R., and Metian, M. (2011). Demand and supply of feed ingredients for farmed fish and crustaceans: trends and prospects. FAO, Fisheries and Aquaculture Technical Paper. No. 564. Rome: FAO.

Tan S.W., Lai K.S., Loh J.Y. (2018). Effects of food wastes on yellow mealworm Tenebrio molitor larval nutritional profiles and growth performances. EIMBO 2(1): 1-6

Taşbozan, O., \& Gökçe, M.A. (2017). Fatty acids in fish. Fatty Acids, 1, 143-159. http://dx.doi.org/10.5772/65211

Tomberlin, J.K., Sheppard, D.C., and Joyce, J.A. (2002). Selected life history traits of black soldier flies (Diptera: Stratiomyidae) reared on three artificial diets. Annals of the Entomological Society of America. 95: 379-386. https://doi.org/10.1603/0013-8746(2002)095

Toriz-Roldan, A., Ruiz-Vega, J., García-Ulloa, M., HernándezLlamas, A., Fonseca-Madrigal, J., and Rodríguez-
González, H. (2019). Assessment of dietary supplementation levels of black soldier fly, Hermetia illucens, Pre-Pupae meal for juvenile Nile tilapia, Oreochromis niloticus. Southwestern Entomologist. 44(1): 251 - 259. https://doi.org/10.3958/059.044.0127

Tschirner, M., and Simon, A. (2015). Influence of different growing substrates and processing on the nutrient composition of black soldier fly larvae destined for animal feed. Journal of Insects as Food and Feed. 1(4): 249-259. https://doi.org/10.3920/JIFF2014.0008

Van Huis, A., Van Itterbeeck, J., Klunder, H., Mertens, E., Halloran, A., Muir, G., and Vantomme, P. (2013). Edible insects: future prospects for food and feed security. Food and Agriculture Organization of the United Nations (FAO), Rome, Italy, FAO Forestry Paper no. 171, 201 pp. http://www.fao.org/docrep/018/i3253e/i3253e

Veldkamp, T., Van Duinkerken, G., Van Huis, A., Lakemond, C.M.M., Ottevanger, E., and Boekel, M.A.J.S. (2012). Insects as a sustainable feed ingredient in pig and poultry diets - a feasibility study. Report 38, Wageningen UR Livestock Production, Wageningen, the Netherlands. pp. 1-48.

Wang, Y. S., and Shelomi, M. (2017). Review of black soldier fly (Hermetia illucens) as animal feed and human food. Foods. 6 (10): 91. https://doi.org/10.3390/foods6100091

Wang, H., ur Rehman, K., Feng, W., Yang, D., Rehman, R., Cai, M., and Zheng, L. (2020). Physicochemical structure of chitin in the developing stages of black soldier fly. International Journal of Biological Macromolecules. 149: 901-907. https://doi.org/10.1016/j.ijbiomac.2020.01.293

Zhang, J., Zheng, L., Jin, P., Zhang, D., and Yu, Z., (2014a). Fishmeal substituted by production of chicken manure conversion with microorganisms and black soldier fly. In: Abstract book of the international conference 'Insects to feed the world', 14-17 May 2014, Ede, the Netherlands. pp. 14-17.

Zhang, J., Zheng, L., Jin, P., Zhang, D., and Yu, Z. (2014b). Kitchen waste converted by black soldier fly and partly substituting soymeal in chicken feed. In: Abstract book of the international conference 'Insects to feed the world', 14-17 May 2014, Ede, the Netherlands. pp. 14-17.

Zhang, J.B., Huang, L., He, J., Tomberlin, J.K., Li, J.H., Lei, C.L., Sun, M., Liu, Z.D., and Yu, Z.N. (2010). An artificial light source influences mating and oviposition of black soldier flies, Hermetia illucens. Journal of Insect Science. 10: 202.https://doi.org/10.1673/031.010.20201

Zheng, L., Hou, Y., Li, W., Yang, S., Li, Q., and Yu, Z. (2012). Biodiesel production from rice straw and restaurant waste employing black soldier fly assisted by microbes. Energy. 47: 225-229. https://doi.org/10.1016/j.energy.2012.09.006

Zhu, K.Y., Merzendorfer, H., Zhang, W., Zhang, J., and Muthukrishnan, S. (2016). Biosynthesis, turnover, and functions of chitin in insects. Annual review of Entomology. 61: 177-196. https://doi.org/10.1146/annurev-ento-010715-023933

Zurbrügg, C., Dortmans, B., Fadhila, A., Verstappen, B., and Diener, S. (2018). From pilot to full scale operation of a waste-to-protein treatment facility. Detritus. 1(1): 18. 